\title{
Back to Basics
}

\author{
by Marco Antonio Vieira \\ Department of Political Science and International Studies, \\ University of Birmingham, UK
}

(FINNEMORE, Martha and GOLDSTEIN, Judith (eds.). Back to Basics: State Power in a Contemporary World. Oxford: Oxford University Press, 2013)

$\mathrm{T}$ he increasing cross-border use of drones, the transnational and elusive phenomenon of cyber espionage and warfare and the ineffectiveness of conventional states' responses to non-traditional security threats such as international terrorism highlight some of the complexities involved in understanding state power in the $21^{\text {st }}$ century. In the straightforward realist narrative, states are the main players in world politics and power is a reflection of states' material capabilities. Military capacity, in particular, is the ultimate source of states' power. Yet, notwithstanding the still solid appeal of the hard power-based realist definition, it does not seem to fit with contemporary international phenomena. The growing number, diversity and relevance of non-state actors, such as international organisations, networked global communities of activists, failed states, multinational corporations and private individuals with a global reach, have fundamentally challenged the state-centric ontology of realism. Likewise, the inability of the United States, still the mightiest state in the world, to translate its economic and military capabilities into desired foreign/defence policy outcomes suggests that conceiving power simply in terms of tangible resources is limiting of a complete understanding of the concept.

Back to Basics evaluates the multiple dimensions of state power in the contemporary world. It pays due homage to Stephen Krasner's groundbreaking and wide-ranging scholarship on the sources and effects of state power in international politics. The volume's editors specifically ask some of the most renowned scholars in the field of International Relations theory "to reflect on the role of state power plays in contemporary politics and how a power politics approach is still relevant to theoretical issues in political science today" (pp. ix). The volume sets out to advance three major areas which underlie Krasner's 
work: (i) it engages with the question of what state power actually is and how it impacts on contemporary world politics; (ii) it conceptually broadens the analytical scope of the international (structural) environment wherein state power is applied and creates effects and, finally; (iii) it discusses the contemporary malleability of sovereignty which makes the exercise of state power extremely complex to understand.

Back to Basics is a challenging book to review given that state power in contemporary politics, in itself a complex subject to conceptually grasp, has been approached by the volume's authors from quite different theoretical and empirical angles. The underlying message in all contributions is quite simple though: traditional material-based explanations of power in international relations scholarship are still useful yet largely insufficient. The book is structured in five sections. In the first section, the editors set the stage by laying out the volume's central puzzles and comprehensively discussing the varied conceptualisations of power in the realist literature and beyond. Keohane's essay, provocatively titled 'Stephen Krasner: Subversive Realist', develops an interesting argument about Krasner's profound contribution and self-identification to, yet combative relationship with, the realist tradition in the discipline of International Relations. Drawing on Krasner's and his own previous work, Keohane suggests that the concept of persuasion provides an interesting analytical basis for understanding the operation of non-material sources (institutions, information, ideas and identity) of state power.

The chapters in the second section of the book reflect on sovereignty and power, two central notions in Krasner's work. Like Keohane with 'persuasion', Lake explores 'authority' as an under-theorised concept in IR. Lake emphasises the relevance of authority as a source of non-coercive power. Authority relations, he argues, are dependent upon the collective and socially constructed acceptance by states of the authority of others over different issue-areas. There is a clear connection here between Lake's argument and well-established discussions on legitimacy, recognition and authority. English School authors, particularly Ian Clark, have emphasised similar social dynamics of legitimacy building while constituting and expanding the 'society' of states. Also in the social constructivist camp, Katzenstien's essay points to the pervasive power of civilizational ideas associated with the United States. According to him, the American empire is first and foremost constituted and maintained by firmly entrenched, albeit increasingly disputed, ideas and values that shape international institutions and regulate the behaviour of actors. Risse's chapter picks up from Krasner's famous discussion of sovereignty as organised hypocrisy to suggest that limited statehood does not necessarily leads to inefficient provision of public goods. The author analytically detaches the often-entangled notions of statehood and governance to persuasively claim that 'new modes of governance [involving a combination of state and non-state actors] are often effective even in the absence of consolidated 
statehood' (pp.79). The interesting essay by Solingen provides 'three scenes of sovereignty and power' (pp.105). The author also draws from Krasner's idea of contradictory or 'hypocritical' sovereignty to reveal three different situations (the ascent of China, variation within and across regions and the global non-proliferation regime) whereby the full exercise of 'sovereign rule' is consequential to and dependent upon domestic, regional and global political dynamics.

In section three of the book, Cohen, Steinberg and Gourevitch dissect the relationship between state power and global economic forces with excellent pieces on currency politics, international trade laws/regimes and the 2008 global financial crisis, respectively. The fourth section, with chapters by Stein, Gruber and Drezner, is dedicated to the phenomenon of globalization and its alleged 'subversive effects' on the Westphalian (state-centred) global order. Finally, in section five, two chapters by Jervis and Krasner wrap up the collection with reflections on state power in an increasingly complex global system. Jervis discusses power as a type of cause and effect relationship with cuts across all forms of social interactions. His argument is tied with the notion of responsibility understood in terms of how 'acts and actors caused various outcomes' (pp.332). Stephen Krasners' final chapter draws on Barnett's and Duval's (2005) taxonomy of power to organise the book's essays according to four kinds of power: compulsory, institutional, structural and productive.

The book's most glaring omission - albeit unsurprising given its predominantly North-American intellectual orientation - is an alternative conceptual treatment of state power drawing from post-positivist theoretical ideas. For instance, the many adaptations of Foucault's and Gramsci's work to the discipline of International Relations have provided useful insights for a critical understanding of the interconnectedness between knowledge, power and hegemony in contemporary world politics. Sections three and four of the book in particular would be analytically enhanced by a Marxist/Gramscian theory of power focusing on how the structure of the global capitalist system fundamentally determines both the material and non-material power capabilities of states. ${ }^{1}$

Furthermore, the volume has only glossed over, or neglected altogether, very important and novel global political/security dynamics with clear implications to the operation of state power in contemporary world politics. The deployment of unmanned drones -almost always used in sharp violation of sovereignty -, the growing challenge posed by cyber warfare/espionage/terrorism and the increasing salience of global networks of political activists are just a few examples of how perilous the geopolitical power of states is in the early $21^{\text {st }}$ century. Notwithstanding the volume's largely conceptual and theoretical focus, it would benefit, and be empirically enriched by an analytical engagement with at least some of these issues. In fact, a more empirically and global security focused application of 
Krasner's proposed conceptual framework might be an interesting follow on collection by the editors.

The above criticisms are not to detract at all from what is otherwise a fine contribution. We should definitely welcome a volume that attempts to rigorously bring state power back front and centre in international relations research. The main contribution of the book is to thoroughly demonstrate how insufficient the traditional realist approaches are to apprehend the complex dynamics of contemporary world politics. In light of the arguments presented in Back to Basics, it seems quite clear that analyses of state power in the $21^{\text {st }}$ century necessarily need to take seriously non-material sources of power. This collection will be a valuable resource for students of international relations interested in critically rethinking conventional conceptualisations of state power along the lines proposed by the essays in the volume.

\section{References}

BARNETT, Michael and DUVALL, Raymond. (2005), Power in International Politics. International Organization, vol. 39, pp. 39-75.

CLARK, Ian. (2005), Legitimacy in International Society. Oxford: Oxford University Press.

SAULL, Richard. (2008), Empire, Imperialism, and Contemporary American Global Power. International Studies Perspectives, vol. 9, $\mathrm{n}^{\circ}$ 3, pp. 309-318.

\section{Notes}

1 See, for example, Saull (2008). 